\title{
Overview of Ghana's Export and Import, FDI inflow and outflow: Is there any connection between its trading partners and the source of its foreign investing countries?
}

\author{
Evans Yeboah a, *, Yu Jing a, Anning Lucy a \\ a Graduated from Nanjing University of Science and Technology, China. \\ *Corresponding author email: yeboahevans56@yahoo.com
}

DOI: https://doi.org/10.34256/ajir20236

Received: 11-04-2020

Accepted: 30-09-2020

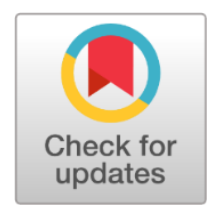

\begin{abstract}
Foreign direct investment inflows and outflows, export and import are seen as some of the major factors for transforming a country's economic growth and development. This paper provides and evaluate literature review on importation and exportation alongside inward and outward FDI in Ghana. By considering some selected countries such China, India, the United States of America, and the United Kingdom in determining whether there is some sort of connection between Ghana's trading partners and investing countries in its economy by the use of quantitative method. The results show that Ghana's export values have improved rapidly over the past years with a continuous decrease in its imports. The outcome further proves that, at the initial level, export from Ghana to China, India, US and UK were of lower values and with much effort by the Ghana government to control the balance of trade deficit from these major trading partners is in the process of achieving the goal, as the country has been experiencing balance of trade surplus from China and India except in the situation US and UK. It was also revealed that China, India, US and UK are not only major trading partners, but also top investing nations in Ghana. It is suggested Ghana should increase its outward FDI and also encourages its multinational companies to embark on cross-boarder investment.
\end{abstract}

Keywords: Export, China, Import, India, UK, US.

\section{Introduction}

The flow of foreign direct investment, export and import of goods and services provide both positive and negative influences on a country's economic growth and development. After 62years of independence and a fall into economic crisis in 1998 as a result of a fall in global price of raw materials made a Ghana comeback in terms of reforming and restructuring its economy. The commodity price shock of 1999 is a clear example between 1998 and 2000, a fall in world commodity prices affected the economy with a negative 20\% drop in Ghana's GDP growth rate (IMF, 2012). Ghana's major export trading commodities are minerals and raw material (gold, cocoa, bauxite, timber etc.) and imports manufactured products. Ghana's major trading partner continue to be the 
European Union, United States and China. Conversely, China's strategic and the immense height of investment, and trade with most African countries has become a major concern for international observing community. Imports are of extreme importance to a resource-constraint developing economy, such as Ghana for development (E.F. \& J, 2009). The majority of Ghana's consumption of manufactured products come from imports from other foreign nations. Between 1960 and 2002 manufactured imports have constituted about $65.28 \%$ of merchandise imports (World, 2004). However, Ghana has a long standing modest history of foreign direct investment attraction (FDI). In more recent times - the 1970s - FDI was mainly in import-substitution manufacturing (United, 2003). The come to trust in foreign direct investment by most African countries led to several changes in their investment policies and structural reforms. With the introduction of the Economic Reform Program (ERP) in 1983, Ghana undertook a relatively successful transition from an administrative system of economic management to a market economy (United, 2003). Economic and political restructuring in many countries and eventually entered into the Word Trade Organization (WTO) brought about signing numerous trade agreements among developed, developing and least developed nations to foster and promote developmental and investment goals.

The recent trend of FDI inflows in Ghana has been a significant influence which draws many investors to invest in the Ghanaian economy. Annual inflows were as high as $\$ 68$ million for about two years, but were much less in most years, even slipping to negative numbers (net outflows) in the late 1970 s, and hovering at under $\$ 5$ million in the mid-1980s (United, 2003). As such, the role of FDI in the development of any particular economy cannot be underestimated, and notwithstanding this fact, there happens to be various dimensions in relation to defining FDI
(Kwasi \& Yao, 2017). FDI inflow benefited Ghana's economy through its effect on agricultural exports, firm productivity, industrial output, stock market and ultimately GDP and GDP growth (Justice \& Gloria, 2012). Foreign direct investment has brought forth many improvements and changes in Ghana's economy ranging from infrastructural and technology. Foreign direct investment (FDI) has been an important source of economic growth for Ghana, bringing in capital investment, technology and management knowledge needed for economic growth (Tee, Larbi, \& Johnson, 2017) The Organization for Economic Co-operation and Development (OECD) in its Third Edition, Benchmark Definition of FDI (BD3) stated that, "FDI reflects the objective of obtaining a lasting interest by a resident entity in one economy in an entity resident in an economy other than that of the investor" (OECD, 1996) . As the flow of foreign direct investment, export and import enable countries to enjoy from goods and services they cannot produced serve as a platform of eliminating hunger and poverty across the world with Ghana not being an exemption, this paper seeks to focus on the overview of export, imports and FDI inflow and outflow in the Ghanaian economy. However, the first part of this study will focus on general export and import of Ghana's economy, whereas the second section will target on FDI inflows and outflow.

\section{Ghana's Export and Import}

Ghana is a net importer of goods and service; net importer is 25 percent of gross domestic product (GDP) in $2005^{1}$. Most imported products for domestic consumption. Conversely, the country export electricity power to neighboring nations such as Togo and Cote Devior. International trade is indispensable to Ghana's economic growth and

\footnotetext{
${ }^{1} \mathrm{http}: / /$ www.commonealthofnations.org/sectorsghana/business/import_and_eport/
} 
development. Merchandise imports as a share of GDP have expanded substantially, from $29 \%$ in 1993 to 39\%, in 1998 (E.F. \& J, 2009). Before the discovery of the jubilee field Ghana was importing huge volume of crude oil for local consumption. Fuel and energy, mainly oil, accounted for 16 percent of 1990 imports; capital goods, 43 percent; intermediate goods, 28 percent; and consumer goods, 10 percent, according to the World Bank (World, 2004). However, with the current government motive to improve upon Ghana's export through the one district-one factory(1D1F) program, thereby reducing import would lead to stabilizing its economy. Promoting exports could directly lead to economic development either through encouraging production of goods for export or allowing accumulation of foreign exchange which enables the importation of capital inputs (Victor, 2012). Ghana's import of goods and service volume were lower in the late $90 \mathrm{~s}$ as a result of a small population size. A total of $\$ 1,318$ million worth of goods was imported into the country in 1991 as against \$1,204.96 million imports in 1990, suggesting about 9.4 per cent growth (Victor, 2012). As Ghana's population size increase with less manufactured products domestically, the demand for imported goods and services expand as the country importation reached US\$17.76 billion in 2012 .

Ghana's merchandise import trade comes from different nations. There are many types of products imported into the country's economy for its local consumption. However, the following are some of the products, agricultural products, non-agricultural products, trade in service, transport, travel and industrial property. According to the World Trade Organization(WTO) on Ghana's trade profile statistics, the total breakdown of the total imports in 2016 was mainly commodity in percentage share are as follows,13.3 percent of agricultural products, 2.6percent fuels and mining products, manufactures 67.6 percent and other products accounted for 16.4 percent. However, the main origin of these imported products are 31.3percent from the European Union, 17.3percent from China,7.8 percent from the United States of America,4.6percent from India,2.9percent from South Africa and 36.1percent from other nations in 2016.

Table 1. Top five agricultural and non-agricultural export and import of Ghana

\begin{tabular}{|l|l|l|l|}
\hline \multicolumn{2}{|c|}{ EXPORT } & \multicolumn{2}{|c|}{ IMPORT } \\
\hline Agricultural Products & $\begin{array}{l}\text { Non-Agricultural } \\
\text { Products }\end{array}$ & $\begin{array}{l}\text { Agricultural } \\
\text { Products }\end{array}$ & $\begin{array}{l}\text { Non-Agricultural } \\
\text { Products }\end{array}$ \\
\hline $\begin{array}{l}\text { Cocoa beans(Whole or } \\
\text { Broken }\end{array}$ & Gold & $\begin{array}{l}\text { Motor cars for transport } \\
\text { of persons }\end{array}$ \\
\hline $\begin{array}{l}\text { Coconuts, Brazil nut, } \\
\text { Cashew nuts }\end{array}$ & Petroleum oil, Crude & Wheat and Meslin & $\begin{array}{l}\text { Motor cars for goods } \\
\text { transport }\end{array}$ \\
\hline $\begin{array}{l}\text { Other oil seeds, } \\
\text { Oleaginous fruits }\end{array}$ & $\begin{array}{l}\text { Woos sawn or chipped } \\
\text { lengthwise }\end{array}$ & $\begin{array}{l}\text { Cane and beet sugar } \\
\text { Wheat or Meslin flour } \\
\text { than crude }\end{array}$ & $\begin{array}{l}\text { Petroleum oils other } \\
\text { aluminous cement }\end{array}$ \\
\hline $\begin{array}{l}\text { Palm oil and its } \\
\text { fractions }\end{array}$ & $\begin{array}{l}\text { Other inorganic acids } \\
\text { fractions }\end{array}$ & $\begin{array}{l}\text { Meat and edible offal } \\
\text { of poultry } \\
\text { fish fillet }\end{array}$ \\
\hline
\end{tabular}

Source: WTO 
Merchandise export trade from Ghana are in the form of agricultural products, nonagricultural products, trade in commercial service, transport, travel, other commercial services and goods-related services and industrial property. However, agricultural export products accounted for 33percent, fuels and mining products 14.1percent, manufactures 8.1percent and 44.8 percent for other nations in 2016, whereas the main destinations were 17.5percent to Switzerland, 14.6percent to India, 13.4percent to the United Arab Emirate(UAE), 13.3percent to the European Union, 8.8percent to China and 32.3percent to other countries in the same year. The table 1 shows Ghana's top export and import products. The table 1 below shows top five agricultural and non-agricultural export and import of Ghana.

\section{Literature Review}

As a result of limited published papers or articles on Ghana's export and import by many researchers and scholars, this literature review will focus on all studies relating to export and import targeting on Ghana specifically. (E.F. \& J, 2009), estimating an aggregate import demand function for Ghana as imports being very important for the survival of small open economy such Ghana with the authors estimating an import demand function for Ghana for the time frame of 1970 to 2002 , as well as taken into account the time series properties of data. The time series behavior of data indicates a long term relationship between real exchange rates, gross domestic product (GDP) and merchandise imports. However, the authors further argued that, their empirical estimates suggest that, real income, gross domestic product is the ultimate factor influencing imports in Ghana and the outcome also showed that, economic growth (real gross domestic product) and depreciation in the domestic currency could encourage increased demand for merchandise import. Conversely, a further analysis brought forth that, shocks to imports, real domestic product and real exchange rate are significant in explaining various innovations in the error variance of each of the variables at different horizons and at a different magnitude.

(Victor, 2012), a study of import demand and economic growth analysis in Ghana; the study disclosed that import trade plays an important role in Ghana's economic growth. However, the trend analysis of the volume of imports, quality of imports and import elasticity's over the study interval propose that import trade contributes to economic growth as evidenced by an expanded import of intermediate and capital goods using the normalized equation from the Johansen Co-integration methodology established a long run relationship between import trade, income, foreign reserves, exchange rate and local price.

(Apana \& Evans, 2018), a study on foreign direct investment inflows and outflows in Ghana and its export and import, the authors studied the effect of FDI inflows and outflows, export and import from the perspective of their influence on gross domestic product (GDP) and economic growth of the Ghanaian economy by evaluating how the values of inward and outward becoming a major source of revenue and strategic development with lower attention to outward FDI. By taken in account the total values of FDI inflows and outflows, general export and import revealed that there is a direct relationship between export and import on the GDP and overall growth rate, and it was further indicated that imports have expanded massively between 2012 and 2016 whereas exports have been reduced. 
(Nicholas, 1996) the importation of paper and consumption patterns in Ghana undertaken to show trends in import of pulp and paper products in Ghana's economy from 1961 to 1994 and the number of waste generated at the printing places. The outcome of the import study indicated that the total imports are intimately connected with socioeconomic growth and political stability of the nation. The study comparing export performance from seven agricultural commodities prior to, during and after initiation of the agricultural diversification project from 1991 to 1999 in Ghana. (David, 2014), in order to aid in identifying the impact of the initiative on Ghana's agricultural exports and to obtained the ability or otherwise of the country to sustain or improve on performances observed under the project with a selected time frame of years 1987 to 2011, the study primarily made use of secondary data on commodity and aggregate agricultural export values for Ghana and the world, the latter being used as the reference group by the use of CEP, SCEP and $\ln$ (CEP) indices were used and based on newly developed thresholds, commodities were placed under the categories "Highly Competitive", "Competitive", "Weakly Competitive" and "Uncompetitive". The results show that besides cocoa and pineapples which were "Highly Competitive" in export performance before initiation of the project, only rubber exports witnessed major improvement among the five other commodities during the project phase.

(Nomfundo \& Nicholas, 2017), to provide an overview of the structure and performance of Ghana's imports, specifically consider the effect of the country's historical trade policy reform and other determinants during the period of 1995 to 2014 of which the results proved that, over this period, the country successfully established a few bilateral trade agreements with African and nonAfrican countries. A larger share of Ghana's imports originates from developed countries and also leading import sources for Ghana at a continental level include Europe, Asia, and Africa.

In this review, most of the authors focused on the importation of certain commodities and products without considering the overall exportation of goods and services. However, the depreciation of the local currency could not encourage imports only, but rather increase the cost of importing manufactured products into Ghana's economy thereby shifting much burden onto the final consumers. As argued by Victor on import demand and economic growth analysis in Ghana as increased in imports of intermediate and capital goods lead to economic growth was focused only one side effect of imports on the country's economic growth. In a situation where a country imports most of its consumed products from other countries with less exports could cause a decline in economic growth. In our situation of this study, we are investigating whether there is a connection between Ghana's import and export trading partners with some of its top investing countries in its economy. As bilateral relationships and being members of some major recognized international organizations promote trade and investment.

\section{Research Methodology and Data Sources}

The purpose of this study is to analyze whether there is any connection between Ghana's export and import trading partners and the sources of FDI flow in the Ghanaian economy over the past years. Observing the trend of export, import and foreign direct investment inflow, from some selected nations 
and their contributions to Ghana's economic growth. As the trend of export and import destinations, foreign direct investment becomes very difficult to observe as a result of changes in data on the various nations on a yearly basis. With respect to this study there is a meaningful data available for these selected countries concerning export and import partners, and the top investing countries in Ghana. In this case, to execute the target outlined in this paper, a quantitative method is considered and the intention of taken into account this procedure is as a result of its robustness in identifying patterns and trends among the data acquired for the purpose of this study. The selected countries are China, India, US and the UK.

According to the literature review of this paper, it can be observed that the majority of studies have not been conducted in this mode, therefore limited amount of conceptual framework for the concept of hypothesis testing. The main set of data will focus on the overall total values of export and import, foreign direct investment inflow and outflow, before considering the percentage share contributions of these selected countries. The study makes use of secondary sources of data and reviewed data on total export and import trading, and foreign direct investment inflow and outflow from some selected countries in Ghana's economy between 2010 and 2017 from stastista, United Nation Conference on Trade and Development (UNCTAD), World Integrated Trade Solution (WITS) and Ghana Investment Promotion Centre (GIPC) investment reports from 2013 to 2017. However, other sources of data from published papers, literature reviews, working papers and reports were also taken in account.

\section{Total Export and Import of Ghana}

Ghana's export and import values have been inconsistent as there is a lower competitive international trading of goods and services. As a result of instability in the country's currency, exporters and importers are exposed to higher cost of doing international trading to and from other nations. A detailed data on Ghana's export and import amounts in the table 2 below.

Table 2. Ghana's total export and import values

\begin{tabular}{lll}
\hline Year & Exports(US\$ billion) & Imports(US\$ billion) \\
\hline 2010 & 7.96 & 10.92 \\
2011 & 12.79 & 15.84 \\
2012 & 13.55 & 17.76 \\
2013 & 13.75 & 17.60 \\
2014 & 13.22 & 14.60 \\
2015 & 10.32 & 13.47 \\
2016 & 11.14 & 12.91 \\
2017 & 13.84 & 12.65 \\
\hline
\end{tabular}

Source: Statista 2019 


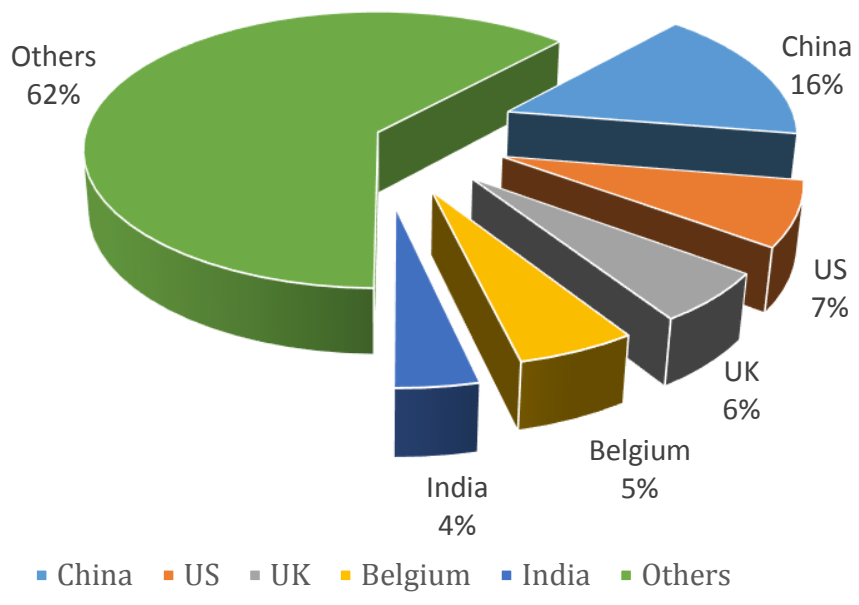

Figure 1 Ghana's import share by countries for 2017

Source: Statista 2019

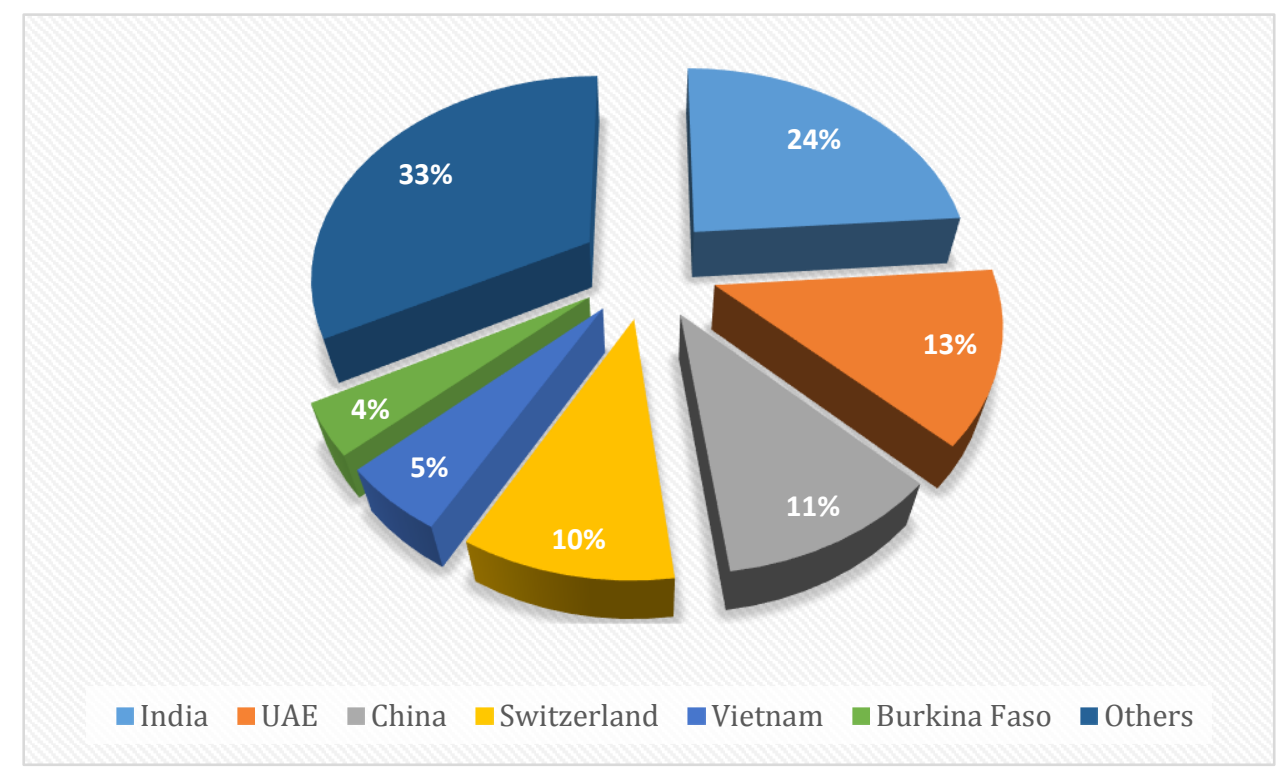

Figure 2 Export destination of Ghana's for 2017

Source: Statista 2019

From the table 2 above shows that, the total import started increasing from 2011 whereas export expanded as well. However, between 2014 and 2016 there was a relatively decline in the general export of goods and services, and a direct inverse relationship on import. importation of goods and services attained a maximum value in 2012 and continued decline in subsequent years. Exportation from Ghana reached its highest value in 2017 as exports exceeded imports showing a balance of trade surplus. China and US remain Ghana's major trading partners in terms of a single country's economy putting 
the European Union aside. The figure 1 and 2 shows the percentage share of nations concerning export and import in 2017.

From figure 2 above clearly shows Ghana imports most of its goods and services from China follow by the United States of America, United Kingdom, Belgium and India. In referring to others which took a greater percentage share represent countries with smaller portions of the total imports combined together. On the other hand, Ghana's export to China is comparatively lower than its imports, with Ghana regularly experiencing trade deficit with China. India as Ghana's main export destination with the highest percentage of the total export is as a result of importing some essential natural resources from Ghana. Ghana equally imports almost all of its pharmaceutical products from India. It can be seen from both figures that Ghana's trading partners varies on a yearly basis.

\section{Import and Export values between China, India, UK and US}

Ghana imports animal, vegetable, food products, minerals, fuel, chemicals, plastic or rubber, hides and skins, wood, textiles and clothing, footwear, stone and glass, metal, machines and electronics, transportation and miscellaneous from these countries. Almost all the commodities or products Ghana's import from China, India, United States of America and the United Kingdom are of similar nature. On the other hand, Ghana also exports same commodity to these countries. The table 3 below shows the breakdown of the value of tariff trading, import partners and Export values of commodities from Ghana to these nations as well.

From the table 3 above shows that Ghana's import from these countries has increased over the years. There were no records on Ghana's import and export captured by the World Integrated Trade Solution for 2014 and 2015. Between 2010 and 2017 Ghana has never attained a trade surplus with the United States and the United Kingdom. However, Ghana only achieved a balance of trade surplus in 2017 with China.

\section{Foreign Direct Investment (FDI) in Ghana}

Foreign direct investment inflow and outflow in Ghana's has been a major significant factor. Foreign Direct Investment (FDI) plays an influential role in the world and helps move the global economy towards an integrated one with a series of interdependent parties (Kwasi \& Yao, 2017).

Table 3.Ghana's import and export from and to China, India, UK and US from 2010 to 2017

\begin{tabular}{lllllllll}
\hline Year & \multicolumn{2}{l}{ Ghana's Import (US\$M) } & \multicolumn{5}{c}{ Ghana's Export (US\$M) } \\
\hline & China & India & UK & US & \multicolumn{1}{c}{ China } & India & UK & US \\
\hline 2010 & $1,060,925.47$ & $319,996.62$ & $387,535.39$ & $1,101,260.29$ & $51,253.32$ & $48,550.27$ & $175,773.72$ & $102,800.49$ \\
2011 & $2,062,109.48$ & $578,739.98$ & $607,366.93$ & $1,307,250.63$ & $257,852.60$ & $722,193.87$ & $355,984.90$ & $444,851.15$ \\
2012 & $2,407,441.62$ & $595,994.86$ & $729,373.77$ & $1,566,864.66$ & $626,810.29$ & $237,314.00$ & $245,356.24$ & $296,699.84$ \\
2013 & $2,280,469.72$ & $608,808.93$ & $541,870.93$ & $1,259,242.24$ & $457,593.75$ & $465,811.34$ & $279,437.26$ & $326,171.66$ \\
2014 & - & - & - & - & - & - & - & - \\
2015 & - & - & - & - & - & - & - \\
2016 & $1,963,589.97$ & $527,622.10$ & $1,106,716.97$ & $881,810.05$ & $941,809.72$ & $1,557,740.79$ & $95,175.57$ & $19,985.20$ \\
2017 & $2,134,176.11$ & $633,288.86$ & $1,099,103.12$ & $1,200,057.70$ & $2,381,361.08$ & $2,689,424.01$ & $329,469.63$ & $407,970.07$ \\
\hline
\end{tabular}


Foreign direct investment attraction is currently used to fuel economic development both the host and investing countries. The contribution that FDI can make to their economic development and integration into the world economy is widely recognized and for this reason, African countries have made considerable efforts over the past decade to improve their investment climate (Samuel, 2012). As a result of Ghana achieving a stable political environment in the West African subregion and across the entire African continent as most nations have increased resources in terms of investment funding of the Ghanaian economy over the past years. With prudent economic fundamentals demonstrated by the current government has gone a long way to attract many prominent automobile companies to established assembling plants in Ghana. With Ghana's abundance of natural resources, limited technology and expertise to explore these resources for an effective economic development, the nation enjoys technology and skilled labor from other foreign investing countries. Foreign direct investment projects typically involve a transfer of technology and managerial skills from the source country to the receipt country (Patrick, Emmanuel, \& Prudence, 2013). However, there have many arguments by researchers on the impact of foreign direct investment on economic growth. Some authors agreed that FDI contribution towards economic development cannot be underestimated in the hosting countries. As observed most researchers agree that the benefits of FDI outweigh its cost to the particular economies (Musila \& Sigue, 2006). Conversely, FDI does not significantly induce economic growth independently (Carkovic \& Levine, 2002). Foreign direct investment could also not benefit the host nation independently without sound macroeconomic indicators. The performance of FDI can be affected by the host country's macroeconomic situations in respect to the competitive superiority, its political and business atmosphere.

\section{FDI Inflows and Outward FDI}

FDI inflows to Ghana originates from different investors from many nations across the globe. The inflow from some countries have been inconsistent on a yearly basis, whereas other nations continue to invest every investment fiscal year. Investing countries like China, India, the United States of America and the United Kingdom have been among the constant investors, playing a key role in foreign direct investment in Ghana regularly. Ghana enjoys United Kingdom's outward foreign direct investment in world as Ghana is a member of the commonwealth of nations and the UK as a colonial master in Ghana. Foreign direct investment inflow continuous to growth from year to year in the early 2000s. However, the inflow values in the 90s were of lower volume as compared to the present years. Investment inflow into the Ghanaian economy stood at US\$14.8milloin in 1990. Inflows value increased to US\$233million in 1994 as a result of the existence 1992 constitution, which made Ghana's democracy and political environment suitable for investors. There was an indirect continuous declined between 1995 and 1999. Conversely, there was a massive expansion in the value of inflows between 2005 and 2006 as the value increased from US\$145million in 2005 to US\$636million in 2006. Since 2006 foreign investment inflow values to Ghana have been improved significantly with Ghana attaining the highest recipient of FDI inflows in the West African region, according to the Ghana Investment Promotion Centre reports but relatively declined in the registered projects over the past years. 
Ghana's outward foreign direct investment has been in smaller values as individual investors, government and multinational companies turn not to involve in OFDI across international borders. OFDI on the African continent has become a major challenge facing most countries. According to United Nations Conference on Trade and Development (UNCTAD) yearly report for 2017 indicated that, there were no records on Ghana's OFDI between 1990 and 1995. Ghana depends heavily on FDI inflows from other foreign investors with less attention drawn to its outward foreign direct investment. In Africa the top home economies for outward FDI are mostly from Angola, Botswana, Morocco, Nigeria and South Africa. Nigeria remains the top outward investing nation in the West African region. Ghana's invested US\$ 1.3million in 1996 whereas, OFDI first reached US $\$ 163.3$ million in 1999. It's only in recent years Zoomlion-Ghana limited a waste management expresses company started extending its operations in other African countries.

\section{Total FDI inflows and Outflows}

Foreign direct investment inflow and outflow in Ghana values are important in identifying FDI growth. FDI inflow keeps increasing while outflow is at a slower growth rate. The volume and number of registered projects by foreign investing countries in Ghana are usually used in determining whether there have been an increased or decreased in inflow and outflow. The table 4 below shows values of FDI inflow and outflow.

From the table 4 above clearly shows that, foreign direct investment inflow values are very high compared to outflows from Ghana. It can be clearly seen that the biggest FDI inflow was in 2016. On the other hand, the maximum outflow value from Ghana was in 2015.

Table 4. FDI Inflows and Outflows values between 2010 and 2017

\begin{tabular}{lll}
\hline Year & Inflows(US\$M) & Outflows(US\$M) \\
\hline 2010 & $2,527.4$ & - \\
2011 & $3,237.4$ & 25.4 \\
2012 & $3,293.4$ & 1.1 \\
2013 & $3,226.3$ & 8.8 \\
2014 & & 11.8 \\
2015 & $3,192.3$ & 221.4 \\
2016 & $3,485.3$ & 14.7 \\
2017 & $3,255.0$ & 15.9 \\
\hline
\end{tabular}

Source: UNCTAD

\section{China, India, US and UK Component of FDI inflows}

FDI inflows in Ghana are mainly made up of domestic and foreign investment component. Both components contribute to the total investment in the Ghanaian economy every year. However, the component of foreign direct investment inflow from China, India, US and UK is very significant to the FDI values recorded each investment fiscal period towards the country's economic development However, investment from the US has contributed significantly to the overall impact of FDI inflow into the Ghanaian economy. The United States massive investment in Ghana is as a result of the bilateral relationship between both Countries. An aggregate number about 172 registered projects with an accumulated cost of US\$2,513million from 1994 to 2012. Conversely, with Ghana and China established an official diplomatic ties in 1960 and Dr. Kwame Nkrumah the first president of Ghana helping China to gain 
membership to the United Nations General Assembly brought major investment from China to Ghana. China ranked the number one investing country in Ghana. Between 1994 and 2012 an estimated number of 383 registered projects with the cost of US $\$ 277$ million was owned by the Chinese. Furthermore, India remains the second top investing nation in Ghana with a total number 379 registered projects and with the cost of US\$171 million between 1994 to 2012. The table below shows each nation's FDI value to the total values accumulated in the selected year range.

From the table 5 above clearly show China obtained highest value of FDI contribution base on the number registered projects in Ghana. There were no records on the US value of the total FDI inflow in 2016, although there were some number of registered projects by the US, but they were of lower values and were not captured among the top 10 investment values by the Ghana Investment Promotion Centre.

\section{Matching Export, Import and FDI inflows and Outflow from Ghana}

This section of the paper will target on comparing the total export and import with FDI inflows and outflows from Ghana and this is made up of import from China, India, US, UK, other trading partners and foreign investing nations. This is to determine the significance of Import, Export, FDI inflow and outflow from the selected countries and other nations impact on Ghana's economy. The figure 3 and 4 below are for a total amount of general trading of goods and services from all Ghana's trading partners indicating their contribution to import and export verse their FDI inflow into Ghana.

Table 5. Total FDI values from China, India, US and UK.

\begin{tabular}{lllll}
\hline Year & China(US\$M) & India(US\$M) & US(US\$M) & UK(US\$M) \\
\hline 2013 & 41.91 & 38.44 & $1,213.84$ & 548.38 \\
2014 & $1,609.92$ & 39.83 & 3.01 & 29.12 \\
2015 & 172.2 & 40.33 & 23.28 & 2.19 \\
2016 & 301.53 & 8.02 & - & 49.85 \\
2017 & 232.93 & 453.75 & 15.39 & 55.02 \\
\hline
\end{tabular}

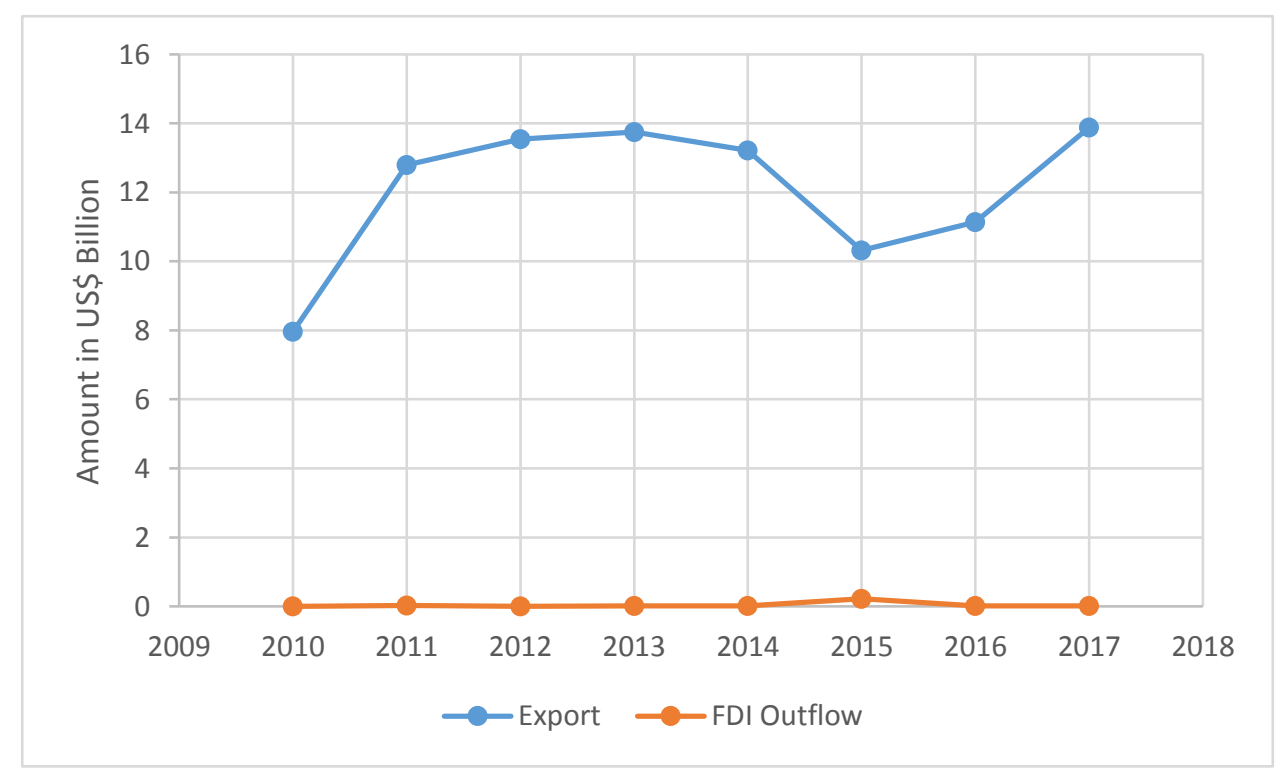

Source: Author calculations base on the data from statista/UNCTAD

Figure 3. Ghana's export values verse FDI outflow value 


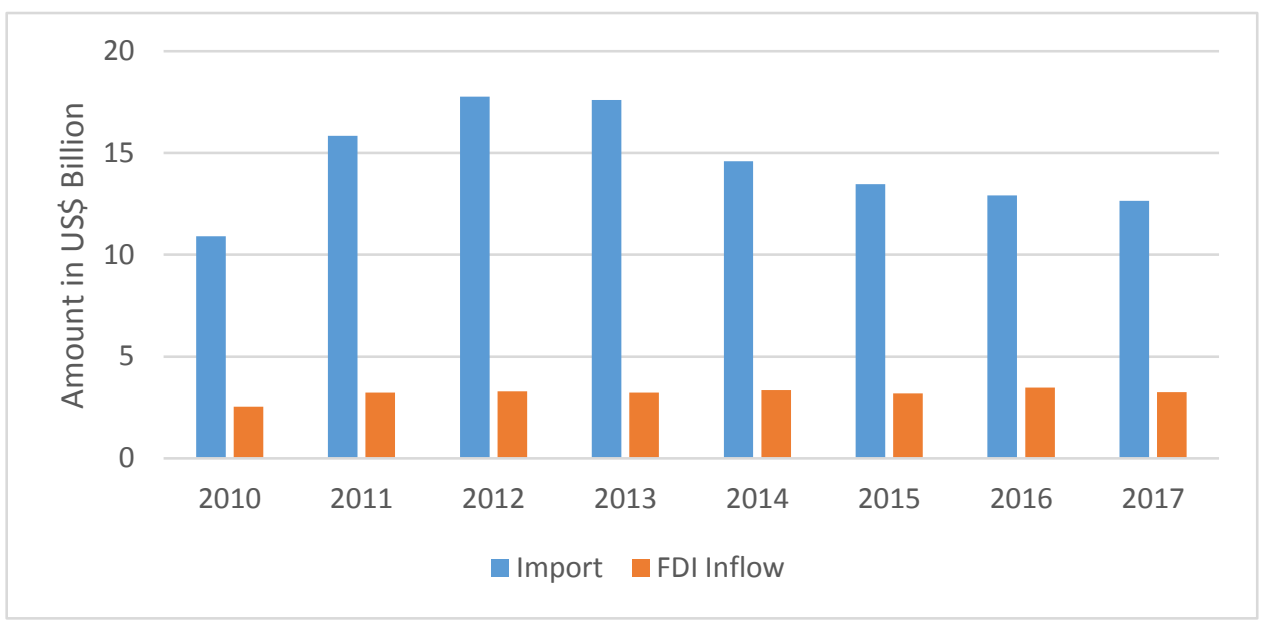

Figure 4. Ghana's Total import verse Total FDI inflow

Source: Author calculations base on the data from statista/UNCTAD

From the figure 3 above clearly shows that export from Ghana continue to increase as outward FDI has been unstable in terms of values. However, the figure 4 below indicates Ghana's import and foreign direct investment inflows in Ghana.

From the figure 4 above shows that, although foreign direct investment values inflow into Ghana have been increasing very rapidly, but comparatively lower than the rate at which Ghana's importation values from other countries expand.

\section{Discussion on Ghana's Situation}

Considering Ghana's export and import situation, Ghana's importation from other countries has been a major challenge for local industries. Major Companies and infant industries collapsed as a result of high demand for foreign imported products with less taste and preference developed by local consumers toward locally manufactured products. However, considering the size of many multinational companies abroad has absolute and comparative advantages over Ghana base companies. Importation and exportation are good for a country to benefit from what it cannot produce and export what it can produce better and in abundance. Looking at
Ghana's importation constantly been exceeding export over the past years has brought much pressure on the local currency (Cedi) through the exchange rate. Depreciation of the Ghanaian currency against major international trading currencies such the euro, dollar and the pounds sterling is as a result of higher demand for them by the local importers. On the other hand, Ghana's commodities for export are mostly in their raw state which gives them lower value on the international market. Ghana can only enjoy a meaningful share of its commodities until embarking on a vigorous industrialized to transform most of these commodities into finished goods.

Conversely, as foreign direct investment values continue to increase with a lower outflow, there is an imbalance of their effects on the country's economic development. With Ghana's depending heavily on inward FDI could cause major challenges in the future as many FDI comes in the form of loans with restrictions attached to them. The location of which these investments is distributed to can also serve as a hindrance to the overall development agenda of Ghana. However, for the country to be able to compete on the international level there is the need to boost outward FDI and also encourage its 
multinational enterprises to embark on crossboarder investment since outward investment from Ghana are not significant and encouraging as little attention is being drawn to it.

\section{Conclusion}

In spite of a rapid increase in export and import, foreign direct investment inflow values, with a lower outward FDI, Ghana continue to benefit significantly from import, export and FDI inflows in building up its economic development and improving upon the lives of its citizens and expatriates. The inflows of FDI will continue to grow as much effort are being done policy makers and the government to improve upon the friendliness of Ghana's business environment in order to attract many investors into the country. This research is to be of importance to Ghana's domestic multinational companies, government, and foreign investor who would want to acquire much insight on export, import, FDI inflow and outflow situation. This may not be enough to capture the benefit and significant Ghana have enjoyed from the number of employment created through importation, exportation, inward and outward FDI, the affected businesses and individual consumers. It is suggested that without a working institution, sound investment policies, favorable condition for exporters from Ghana and implementation of good import restrictions Ghana cannot witness a maximum impact of export, import and FDI inflow in its economy. This will not be applicable to other countries since the ultimate focus was on the analysis of Ghana's situation.

\section{References}

Apana, Gladys and Yeboah Evans, (2018), "FDI Inflows and Outflows in Ghana and its Export and Import." Journal of Economics and Sustainable Development 9.10. 
Carkovic, M. and R. Levine (2002), "Does foreign direct investment accelerate economic growth?" Available from http//siteresource.worldbank.org/INTFR/Resources/fdi pdf accessed on 9th February, 2013.

David, Boansi, (2014), Comparative Performance of Agricultural Export Trade: During and PostAgricultural Diversification Project in Ghana, British Journal of Economics, Management\&Trade 4 (10),1501-1511.

E.F., Oteng-Abayie and Appiah-Nkrumah J, (2009), Estimating An Aggregate Import Demand Function For Ghana, Journal of Science and Technology 29(2).

IMF. "World Economic Outlook: Growth Resuming, Dangers Remain". Washington DC: International Monetary Fund., 2012.

Justice, G.Djokoto and C.Dzeha Gloria (2012), Determinants and Effects of Foreign Direct Investment in Ghana - Review of Literature, Developing Country Studies 2(11).

Kwasi, Boakye-Gyasi and Li Yao (2017) FDI Trend in Ghana: The Role Of China, US, India And South Africa." Eurasian Journal of Economics and Finance 5(2) 1-16.

Musila, J.W and S.P Sigue (2006), Accelerating foreign direct investment flow to Africa: from policy statements to successful strategies, ." Managerial Finance 32(7) 577-593.

Nicholas, A.Darkwa, (1996),Paper Import and Consumption Pattern in Ghana." Ghana Journal of Forestry 3.

Nomfundo, (2017), Portia Vacu and M.Odhiambo Nicholas. "A Review of Imports Structure and Reforms in Ghana." EuroEconomica 36(1).

OECD. OECD benchmark definition of foreign direct investment - Third edition. Paris: OECD, 1996.

Patrick, Enu, Dodzi K.Havi Emmanuel and Attah-Obeng Prudence, (2013), Impact of Macroeconomic Factors On Foreign Direct Investment In Ghana: A Cointegration Analysis, European Scientific Journal 9(28).

Samuel, Kwadwo Frimpong, (2012). Research on Relationship between China and Ghana: Trade and Foreign Direct Investment (FDI). Journal of Economics and Sustainable Development 3.7.

Tee, Evans, Frank Larbi and Rebecca Johnson, (2017), "The Effect of Foreign Direct Investment (FDI) on the Ghanaian Economic Growth, Journal of Business and Economic Development 2(5) 240-246.

United, Nations. Investment Policy Review Ghana. Geneva: UN, 2003.

Victor, Osei (2012), Import Demand and Economic Growth Analysis in Ghana, Journal of Economics and Sustainable Development 3(14).

World, Bank. World Development Indi- cators, CD Rom. Washington D.C.: World Bank, 2004.

Funding: No funding was received for conducting this study.

Conflict of Interest: The authors have no conflicts of interest to declare that they are relevant to the content of this article.

About the License: (C) The author(s) 2020. The text of this article is open access and licensed under a Creative Commons Attribution 4.0 International License 